\section{Grass Mixtures for Seeding Sagebrush Lands ${ }^{1}$}

\author{
A. C. HULL, JR.
}

Range Scientist, Crops Research Division, Agricultural Research Service, U.S. Department of Agriculture, Logan, Utah.

\section{Highlight}

Four wheatgrasses were seeded alone and in mixtures in 1945 near Dubois, Idaho. By 1955, fairway wheatgrass had spread by seed to all plots and has remained the most abundant species. Intermediate and pubescent wheatgrasses spread slower, mainly by rhizomes, and by 1967 , they were present on all treatments. At the end of 25 years these three species are growing well together. Bluebunch wheatgrass has practically disappeared from the study area.

${ }^{1}$ Cooperative investigations of Crops Research and Animal Husbandry Research Divisions, Agricultural Research Service, and Forest Service, U. S. Department of Agriculture; and Utah Agricultural Experiment Station. Utah Agricultural Experiment Station Journal Paper 970. Received January 29, 1970; accepted for publication August 1,1970 .
Mixtures have been recommended for seeding high elevation lands but not for seeding lowland ranges in southern Idaho (Plummer et al., 1955; Hull and Holmgren, 1964). Because mixtures are often seeded, however, this study was initiated to determine long-time relationships of the major wheatgrass species used for seeding in this area in 1945 .

\section{Methods}

This study was conducted at the U. S. Sheep Experiment Station 2 headquarters near Dubois, Idaho. The elevation is 5,500 feet and annual precipitation is 11 inches. The soil is a silt loam underlain by basalt at about 36 inches. This site was sagebrush-grass with threetip sagebrush (Artemisia tripartita Rydb.) and thickspike wheatgrass (Agropyron dasystachyum (Hook.) Scribn.) the major species. There was some big sagebrush (A. tridentata Nutt.), bluebunch wheatgrass ( $A$. spicatum (Pursh) Scribn. and

${ }^{2}$ The U. S. Sheep Experiment Station is maintained by the Animal Husbandry Research Division of Agricultural Research Service, U. S. Department of Agriculture, in cooperation with the Intermountain Forest and Range Experiment Station, Forest Service, U. S. Department of Agriculture, and with the Agricultural Experiment Station of the University of Idaho. 
Table 1. Species seeded (lbs./acre) in the 11 combinations at Dubois in 1945.

\begin{tabular}{cccccc}
\hline \hline \multirow{2}{*}{$\begin{array}{c}\text { Mixture } \\
\text { numbcr }\end{array}$} & \multicolumn{5}{c}{ Species seeded } \\
\cline { 2 - 6 } & Acr & Ain & Asp & Atr & Total \\
\hline 1 & 6 & & & & 6 \\
2 & & 9 & & & 9 \\
3 & & & 10 & & 10 \\
4 & & & & 9 & 9 \\
5 & 3 & 4.5 & & & 7.5 \\
6 & 3 & & 5 & & 8 \\
7 & 3 & & & 4.5 & 7.5 \\
8 & 3 & 2.3 & 2.5 & & 7.8 \\
9 & 3 & 2.3 & & 2.3 & 7.6 \\
10 & 3 & & 2.5 & 2.3 & 7.8 \\
11 & 3 & 1.5 & 1.7 & 1.5 & 7.7 \\
\hline
\end{tabular}

Smith) and a variety of grasses and forbs in lesser amounts. The following 4 species were drilled alone and in mixtures for 11 combinations (Table 1):

\begin{tabular}{|c|c|}
\hline Symbol & Species \\
\hline Acr & $\begin{array}{l}\text { Fairway wheatgrass (Agropyron cristatum (L.) } \\
\text { Gaertn.) }\end{array}$ \\
\hline Ain & $\begin{array}{l}\text { Intermediate wheatgrass (A. intermedium (Host) } \\
\text { Beauv.) }\end{array}$ \\
\hline Atr & $\begin{array}{l}\text { Pubescent wheatgrass (A. trichophorum (Link) } \\
\text { Richt.) }\end{array}$ \\
\hline sp & Bluebunch wheatgrass \\
\hline
\end{tabular}

Seed was drilled in 8-inch rows to a depth of .5 inch on a freshly plowed but firm seedhed on October 20, 1945. Plots were $8 \times 33$ feet and each treatment was duplicated. There was no regular grazing, and plants were grazed lightly as sheep werc being moved through the arca in the spring and fall.

This study was also initiated at two locations near Idaho Falls. Unfortunately, both areas were plowed in 1948. The early life of these stands was similar to those at Dubois.

The success of an established stand or the potential of a seedling stand of grass was made on a rating basis: 9-10, excellent; 7-8, good; 5-6, fair; 3-4, poor; 1-2, very poor; 0 , failure. Ratings were made in 1946, 1947, 1948, 1955, 1967, 1968, 1969, and 1970. Species composition was estimated in 1955, 1967, 1968, 1969 and 1970.

\section{Results}

Seedlings emerged in the spring of 1946. By late May all species had excellent stands, except for one plot of fairway wheatgrass which was rated good. Seedlings were vigorous and height ranged from 4 inches for fairway wheatgrass to 7 inches for intermediate wheatgrass. Many seedlings perished from summer drought in 1946, but in 1947 stands were still fair to excellent.

In 1947 and 1948, a moderate to thick stand of cheatgrass (Bromus tectorum L.) mostly hid the small, seeded grass plants. However, as seeded
Table 2. Estimated composition (\%) of 4 species in 11 combinations in 1955 and 1970 at Dubois.

\begin{tabular}{|c|c|c|c|c|c|c|c|c|}
\hline \multirow{2}{*}{$\begin{array}{l}\text { Mixture } \\
\text { number }\end{array}$} & \multicolumn{4}{|c|}{1955} & \multicolumn{4}{|c|}{1970} \\
\hline & ACr & Ain & Asp & Atr & Acr & Ain & Asp & Atr \\
\hline 1 & $100^{\mathrm{a}}$ & & & & $98^{a}$ & 1 & & 1 \\
\hline 2 & 2 & $98^{a}$ & & & 46 & $50^{a}$ & & 4 \\
\hline 3 & 25 & & $75^{a}$ & & 88 & 5 & $\mathrm{~T}^{\mathrm{a}}$ & 7 \\
\hline 4 & 2 & & & $98 \mathrm{a}$ & 37 & 3 & & $60^{\mathrm{a}}$ \\
\hline 5 & $75^{\mathrm{a}}$ & $25^{\mathrm{a}}$ & & & $84^{a}$ & $14^{a}$ & & 2 \\
\hline 6 & $98^{\mathrm{a}}$ & 1 & $0^{\mathrm{a}}$ & 1 & $96^{\mathrm{a}}$ & 2 & $0^{\mathrm{a}}$ & 2 \\
\hline 7 & $82^{\mathrm{a}}$ & & & $18^{a}$ & $85^{a}$ & 1 & & $14^{a}$ \\
\hline 8 & $85^{\mathrm{a}}$ & $15^{\mathrm{a}}$ & $0^{a}$ & & $78^{\mathrm{a}}$ & $19 \mathrm{a}$ & $0^{\mathrm{a}}$ & 3 \\
\hline 9 & $76^{\mathrm{a}}$ & $14^{\mathrm{a}}$ & & $10^{\mathrm{a}}$ & $74^{\mathrm{a}}$ & $17^{a}$ & & $9^{a}$ \\
\hline 10 & $94^{a}$ & & $T^{a b}$ & $6^{\mathrm{a}}$ & $89^{a}$ & 3 & $T^{u}$ & $8^{a}$ \\
\hline 11 & $70^{\mathrm{a}}$ & $18^{\mathrm{a}}$ & $0^{\mathrm{a}}$ & $12^{\mathrm{a}}$ & $82^{\mathrm{a}}$ & $10^{\mathrm{a}}$ & $0^{\mathrm{a}}$ & $8^{a}$ \\
\hline
\end{tabular}

"Indicates the species was seeded here. Figures with no " $a$ " show spread into plots where not seeded.

b $\mathbf{T}$ denotes a trace.

plants matured and thickened, they crowded out the cheatgrass.

By 1955 stands of individual grasses and mixtures were rated excellent except for one bluebunch wheatgrass plot which was rated good. Bluebunch wheatgrass almost disappeared from most of the mixture plots. Fairway wheatgrass had spread to all plots. The other two species were mainly within their seeded plots and in plots immediately adjacent (Table 2 ).

In 1967 all plots had excellent stands although not always of the species seeded. Bluebunch wheatgrass had almost disappeared and had been replaced, mainly by fairway wheatgrass. Intermediate and pubescent wheatgrass spread into all plots. There was little change from 1967 to 1970.

In 1968 samples were clipped as near ground level as possible. Yields varied from 1,009 to 1,410 with an average of $1,226 \mathrm{lb}$./acre, air dry. Species or mixtures did not significantly affect yields.

\section{Discussion}

This study shows that fairway wheatgrass spreads rapidly by seed. It is the dominant plant on all plots where it was originally seeded, either alone or in mixture. It also comprises $37 \%$ to $88 \%$ of the stand where it was not seeded. Intermediate and pubescent wheatgrasses spread more slowly than fairway wheatgrass. Most of their spread is by rhizomes. Though bluebunch wheatgrass is native to this area it was replaced with introduced wheatgrasses.

Where fairway wheatgrass was seeded with one or both of the two rhizomatous grasses, it increased an average of $2 \%$ from 1955 to 1970 . 
Pubescent and intermcdiatc wheatgrasses averaged a $1 \%$ decrease.

These three wheatgrasses have also spread well on other seedings in this area. In 1946, 12 species were seeded for grazing studies. By 1963 fairway wheatgrass had spread to $438 \%$ of its original seeded area. Pubescent wheatgrass had spread 210\% and intermediate wheatgrass $115 \%$ (Hull and Klomp, 1966).

Studies show that these 3 wheatgrasses are adapted to this area and for 25 years they have grown well together in this study. If used only for early spring grazing this mixture could provide a variety of feed and excellent ground cover. However, if late spring or summer grazing is de- sired, seeded areas now grazed indicate that differential palatability makes it desirable to plant these species singly.

\section{Literature Cited}

Hull, A. C., JR., and Ralph Holmgren. 1964. Seeding southern Idaho rangelands. U. S. Forest Serv. Res. Paper INT-10. $32 \mathrm{p}$.

Hull, A. C., JR., AND G. J. KLomp. 1966. Longevity of crested wheatgrass in the sagebrush-grass type in southern Idaho. J. Range Manage. 19:5-11.

Plummer, Perry, A. C. Hull, Jr., Geogre Stewart, and JosEPH H. RobERTson. 1955. Seeding rangelands in Utah, Nevada, southern Idaho and western Wyoming. U. S. Dep. Agr. Agr. Handbook No. 71.73 p. 